\title{
Dijecezanski biskupi u sinodalnoj Crkvi
}

\author{
Alan Modric**
}

\begin{abstract}
Sažetak
Polazeći od učenja pape Franje o sinodalnosti i sinodalnoj Crkvi, kao i od značenja sinodalnosti u crkvenom pravnom sustavu, članak želi pojasniti važnost $i$ ulogu dijecezanskih biskupa u ostvarenju takve sinodalnosti u crkvenim tijelima na razini biskupije, grupe biskupija i sveopće Crkve. Nastoji se istaknuti potreba uže suradnje između pastira i vjerničkoga puka u kojem bi se još dublje ostvarilo crkveno zajedništvo u skladu sa željom sadašnjega pape za sinodalnim hodom cjelokupnoga Božjega naroda.
\end{abstract}

Ključne riječi: sinodalnost, zajedništvo, sudjelovanje, savjetovanje, dijecezanski biskup

\section{Uvod}

Od samoga početka svojega pontifikata papa Franjo preuzeo je kao programsku smjernicu nastojanje da se hijerarhijska struktura Katoličke crkve što više poveže sa svojom bazom, cjelokupnim Božjim narodom, u zadaći evangelizacije koju je Isus Krist povjerio svojoj Crkvi. Na taj način Sveti Otac nastoji nastaviti i produbiti napore koje su u tom smislu poduzeli njegovi prethodnici u Petrovoj Stolici još od vremena Drugoga vatikanskoga koncila, koji je stavio velik naglasak na kolegijalnom duhu između Zbora biskupa i njihove glave, rimskoga prvosvećenika, ali također i na ulozi čitavoga Božjega naroda u naviještanju Radosne vijesti. Takva uloga nikako ne smije biti smatrana sporednim, nego jednim od glavnih čimbenika u ostvarenju poslanja sveopće Crkve u svijetu.

Jedan od važnijih trenutaka sadašnjega pontifikata u tom smislu svakako je govor pape Franje održan prigodom obilježavanja pedesete obljetnice Sinode biskupa, u kojem se predlaže hod sinodalnosti kao programska obveza za cijelu Crkvu u trećem tisućljeću. Na prvom mjestu Papa ističe sensus fidei (osjećaj vjere) Božjega naroda kao temeljni kriterij vjerodostojnosti takvoga hoda koji sprječava da se strogo odvoji hijerarhija Crkve od vjernika, jer i narod posjeduje

* Dr. sc. Alan Modrić, Papinsko sveučilište Gregoriana u Rimu. Adresa: Piazza della Pilotta 4, 00187 Rim, Italija. E-adresa: modric_a@hotmail.com 
vlastito osjetilo za razlučivanje novih puteva koje Gospodin otkriva Crkvi (Franjo, 2015, 1139-1140).

Sinodalna Crkva je crkva uzajamnoga slušanja svih sastavnica života Crkve: vjerničkoga naroda, Zbora biskupa, biskupa Rima, i u tom se očituje i smjer sinodalnoga hoda, jer on započinje najprije slušanjem Božjega naroda, potom se nastavlja slušajući pastire kao vjerodostojne čuvare, tumače i svjedoke vjere čitave Crkve, te na koncu doseže svoj vrhunac u slušanju rimskoga biskupa, kao vrhovnoga svjedoka vjere čitave Crkve, koji se ipak ne nalazi sam iznad Crkve, nego unutar nje kao kršteni među krštenima, a unutar Zbora biskupa kao biskup među biskupima, pozvan istovremeno — kao nasljednik apostola Petra — voditi Crkvu Rima, koja predsjeda u ljubavi svim crkvama (Franjo, 2015, 1141).

U takvome sinodalnom procesu važnu ulogu, bez daljnjega, trebaju imati pastiri Crkve, a posebice dijecezanski biskupi, kao oni koji su pozvani da izgrađuju i vode povjereni im narod $\mathrm{k}$ sve većemu zajedništvu. Zbog toga u ovom radu stavljamo naglasak na njihovu ulogu u sinodalnoj Crkvi, kakvu nastoji ostvariti u ovim vremenima papa Franjo kao poglavar Biskupskoga zbora. Takva je uloga analizirana s točke gledišta sustava crkvenoga prava, polazeći od određenih općih načela koja se potom nastoje ostvariti u okviru konkretnih crkvenih pravnih tijela u kojima dijecezanski biskupi daju odlučujući doprinos.

\section{Sinodalnost u Crkvi}

\subsection{Crkveno zajedništvo}

Radi boljega razumijevanja značenja sinodalnosti potrebno je objasniti pojam zajedništva. Drugi vatikanski koncil definira Crkvu kao sakrament, znak ili sredstvo intimnoga sjedinjenja s Bogom i jedinstva cjelokupnoga ljudskoga roda (LG 1), te je stoga sveopća Crkva ustrojena kao zajedništvo, na sliku zajedništva između tri božanske osobe (LG 4b).

Prema Ivanu Pavlu II., zajedništvo se oblikuje kao "organsko" zajedništvo, slično onomu u tijelu koje živi i djeluje, koje se odlikuje prisutnošću različitosti i komplementarnosti poziva i životnih stanja, službi, karizmi i odgovornosti (CL 20). Kako se po krštenju nalaze u zajedništvu s Crkvom, svi vjernici posjeduju isti temeljni pravni položaj, zbog čega među njima vlada istinska jednakost u dostojanstvu i djelovanju, s jednakim pravima i dužnostima, što ne znači istovjetnost, zbog razlika među članovima crkvenoga zajedništva utemeljenih na različitosti službi, služenja i funkcija koje se obavljaju u Crkvi i od kojih proizlaze različiti pravni položaji vjernika (AG 4; LG 4a; CIC kann. 204 §1, 208).

Iz crkvenoga zajedništva proizlazi uzajamna odgovornost i sudjelovanje svih u izgradnji Crkve i činjenju njezina poslanja. Na temeljnoj općoj uzajamnoj odgovornosti utemeljene su različite osobne odgovornosti zahtijevane od službe Poglavara, koji na posredan način očituje prisutnost Krista, Glave, kao i različiti oblici sudjelovanja koji izražavaju jednakost, kako između svih vjernika, tako i između vjernika određene kategorije. U svjetlu prisutnosti tih očitovanja uzaja- 
mne odgovornosti, može se zaključiti kako sinodalnost Crkve valja razumjeti kao djelotvoran izraz crkvenoga zajedništva u njezinu organskom ustrojstvu (Ghirlanda, 2005, 75).

\subsection{Sudjelovanje u odgovornosti pastira Crkve}

$\mathrm{S}$ obzirom na pojam sudjelovanja, valja naglasiti da u crkvenom zajedništvu, koje zahtijeva razlikovanje među njegovim članovima, sudjelovanje nosi sa sobom različite odgovornosti među subjektima uključenima u taj odnos: jedna osoba ima potpunu osobnu odgovornost u odnosu na određeni objekt, a drugi djelomično sudjeluju u toj odgovornosti. Taj se odnos sudjelovanja očituje u svakom savjetodavnom predstavničkom tijelu, gdje poglavaru, u njegovoj osobnoj vlasti, pomažu druge osobe koje sudjeluju u njegovoj odgovornosti, nudeći mu informacije, mišljenje ili suglasnost u pitanju o kojem poglavar mora odlučiti. Tako imamo proces oblikovanja odluke, koju će poglavar osobno donijeti, i u tom procesu, koji zahtijeva sama narav Crkve utemeljene na zajedništvu svih vjernika, oni, prema CIC kan. $212 \S 3$, imaju pravo da ih se pita za savjet, kao i dužnost da iznesu pastirima svoje mišljenje o onom što se odnosi na dobro Crkve (Ghirlanda, 2001, 260).

Bitno je naglasiti da opća temeljna suodgovornost i sudjelovanje ne upućuju na to da se u Crkvu uvode pravila modernih političkih demokracija ili parlamentarnih sustava koji se oslanjaju na volju većine, jer oni su radikalno nekompatibilni s naravi vlasti u Crkvi, kojoj je potpuno nepoznata bilo kakva narodna investitura, mandat ili posredništvo na način svjetovnih uređenja.

\subsection{Savjetovanje crkvenih pastira}

Sinodalnost, osim što se odražava kroz organizme s pravom odlučivanja, također je usko povezana s pitanjem traženja savjeta i savjetodavnoga glasa u Crkvi, jer postoje sinodalna savjetodavna tijela, te se stoga postavlja pitanje: što u Crkvi znači "savjetovati"?

Drugi vatikanski koncil na više različitih mjesta naglašava važnost savjetovanja i suradnje od strane vjernika laika. Tako oni, budući da posjeduju znanje, stručnost i ugled, imaju pravo, štoviše ponekad i obvezu, izraziti svoje mišljenje o stvarima koje se odnose na dobro Crkve, a pastiri se, s druge strane, moraju rado služiti njihovim razboritim savjetom kako bi, potpomognuti iskustvom laika, mogli jasnije i svrhovitije prosuđivati o duhovnim i vremenitim stvarima. Na taj način čitava Crkva učinkovitije obavlja svoje poslanje za život svijeta (LG 37). Naime, sama biskupska služba vladanja podrazumijeva saslušanje vjernika za koje se brine, kao i poticaj da velikodušno surađuju s njim (LG 27).

Postoji opasnost da savjetodavni glas i njegova razlika u odnosu na glas odlučivanja dovede do podcjenjivanja mišljenja i glasova iznesenih u različitim tijelima, što se može dogoditi ako se pojam savjetodavnoga glasa shvati prema značenju koje ima u građanskom pravu, u njegovim različitim izričajima. Stoga je potrebno dobro razumjeti značenje savjetodavnoga glasa u crkvenom pravu. 
Vjernici imaju pravo i dužnost savjetovati pastire upravo stoga što su "vjernici” (CIC kan. 212 §3), tj. kršteni. Dva su razloga za traženje savjeta od strane vjernika: a) prvi je ljudsko-sociološke naravi, jer su vjernici sposobni savjetovati o stvarima u kojima su stručni, a pastirima je potrebna pomoć u tim stvarima i/ili mogu biti nesigurni u rasuđivanju; b) teološke naravi, zbog sakramenata krštenja i potvrde (Coccopalmerio, 2000, 28).

U svjetlu svega do sada iznesenoga, postaje jasno kako savjetovanje u Crkvi nema za cilj postizanje većine glasova, što je slučaj u parlamentarnim sustavima, u kojima jedna frakcija nameće svoju volju drugoj, nego traženje istine i dobra Crkve postizanjem suglasnosti. Naime, sinodalnost u Crkvi nije mehanički zakon većine ni jednoglasnost nametnuta od poglavara, nego dijalog koji teži prema jedinstvu mišljenja i namjera (Rovira Belloso, 1997, 82). Pod tim gledištem nije toliko bitno ima li jedno sinodalno tijelo odlučujući ili savjetodavni glas, ili je pozvano dati suglasnost ili mišljenje, jer se u svakom slučaju provodi crkveno zajedništvo i sudjelovanje različitih kategorija vjernika u upravljanju Crkvom, pokazujući na taj način da Duh ne djeluje samo u pastirima koji moraju donositi odluke, nego u svima onima koji im pomažu da oblikuju najbolju moguću odluku za dobro Crkve, što je krajnji cilj vlasti pastira (CIC kan. 127 §2, 2º; Ghirlanda, 2001, 261).

Savjetodavna uloga vjernika nije tek pomoć koju se povremeno nudi pastirima, nego je riječ o autentičnoj i stalnoj funkciji općega svećeništva i nadnaravnoga osjećaja vjere svega naroda (LG 12). Sensus fidei temelji se na zajedništvu u objavljenoj istini, te ga je stoga nemoguće poistovjetiti s kategorijom "javnoga mišljenja” (Vitali, 2001, 703), koje čini zbroj subjektivnih mišljenja, a još manje sa zbrojem mišljenja vjernika suprotstavljenih učiteljstvu pastira. Naime, sensus fidei i naučiteljska služba nalaze se unutar proročkoga služenja Crkve, u kojoj su, s jedne strane, pastiri primili »sigurnu karizmu istine « (DV 8) te svjedoče »vjeru prenesenu svetima jednom zauvijek « (LG 12). S druge strane, ne smiju zanemariti sensus fidei vjernika, te se tako između biskupa i vjernika postiže jedinstvo $\mathrm{u}$ ispovijedanju primljene vjere, zahvaljujući kojoj Crkva »ne može pogriješiti u vjerovanju « (LG 12). To jedinstvo odlučujuće je za ostvarenje crkvene sinodalnosti (Villar, 2018, 11).

\section{Dijecezanski biskupi u crkvenoj sinodalnosti}

\subsection{U odnosu na vlastite vjernike}

Nakon kratkoga pojašnjenja sinodalnosti Crkve, potrebno je razmotriti teološki i pravni položaj dijecezanskih biskupa unutar takve sinodalne strukture. Prije svega, valja analizirati pastoralnu narav njihove službe. Prema Lumen gentium, dijecezanskim biskupima je "potpuno predana pastirska služba, odnosno stalna i svagdašnja skrb za njihovo stado «(LG 27b), koja se očituje, između ostaloga, u saslušanju onih koji ovise o njemu, brinući se za njih kao za svoju istinsku djecu, potičući ih da budu pripravni za suradnju s njim u apostolskoj i misijskoj 
aktivnosti (LG 27c). Dekret Christus Dominus tvrdi da se briga o biskupiji sastoji u činjenici da biskupi, pod autoritetom rimskoga prvosvećenika, pastirski vode vjernike u Gospodinovo ime kao vlastiti, redoviti i neposredni pastiri, te za njihovo dobro obavljaju službu poučavanja, posvećenja i upravljanja (CD 11b), a u obavljanju pastoralne službe poštuju zadaće koje pripadaju njihovim vjernicima u stvarima Crkve, priznajući im obvezu i pravo da aktivno surađuju u izgradnji Kristova mističnoga tijela (CD 16e).

CIC kan. 381 §1 određuje da dijecezanskomu biskupu u povjerenoj mu biskupiji pripada sva redovita, vlastita i neposredna vlast za obavljanje njegove pastoralne službe. Kako proizlazi iz gore navedenih normi i dokumenata, pastoralna je služba ontološki element biskupske službe i cilj radi kojega biskupu pripada sva moć upravljanja u njegovoj biskupiji. Naime, vlast koju biskup prima za skrbljenje o biskupiji proizlazi iz ontološke datosti, jer je postavljen za pastira, a istovremeno je sredstvo njezina ostvarenja (Ghirlanda, 2002, 678).

Pastoralna služba kao ontološka dimenzija biskupske službe u Crkvi prima se sakramentalno, kao dioništvo u Kristovu posvećenju i poslanju (LG 28a). Iz toga ontološkoga dioništva proizlazi činjenica da su biskupi Kristovi zamjenici i poslanici u obavljanju zadaća koje sa sobom nosi pastoralna služba, kako naglašava Lumen gentium: »Biskupi upravljaju njima povjerenim partikularnim crkvama kao Kristovi zamjenici i poslanici« (LG 27a). Posvećenje po kojem biskup prima pastoralnu službu, postavlja ga u odnosu na vjernike kao učitelja, posvetitelja i pastira, kao onoga koji djeluje u ime i u osobi Krista. Međutim, postoji i druga dimenzija dijecezanskoga biskupa, koju očituje njegovo "biti s" ostalim vjernicima kao sin i član Crkve, od koje je primio krštenje i "prvu poduku u vjeri”, te sa svim ostalim vjernicima »dijeli neuništivo dostojanstvo Božjega djeteta, koje treba živjeti u zajedništvu i u duhu zahvalnoga bratstva« (PG 10). Ivan Pavao II. jasno tvrdi: »Biskup postaje ‘ocem' upravo stoga što je potpuno 'sin' Crkve« (PG 10).

Sve do sad izneseno otkriva kako se u osobi biskupa i u njegovoj službi nalazi odnos i uzajamnost između općega svećeništva vjernika i ministerijalnoga svećeništva, koji se očituju u određenom "kružnom odnosu": a) između svjedočanstva vjere svih vjernika i svjedočanstva vjere biskupa u njegovim učenjima; b) između svetoga života vjernika i sredstava posvećenja koje im biskup nudi; c) između osobne odgovornosti biskupa s obzirom na dobro njegove partikularne crkve i suodgovornosti svih vjernika s obzirom na njezino dobro (PG 10).

Govorili smo o crkvenom zajedništvu koje bi trebalo, ako ga se doista živi, dovesti biskupa do pastoralne prakse koja je sve otvorenija suradnji svih, gdje god postoji povezanost između onoga što je biskup s osobnom odgovornošću pozvan odlučiti za dobro njegove partikularne crkve i doprinosa koji vjernici mogu ponuditi preko savjetodavnih tijela, kao što je biskupijska sinoda, prezbitersko vijeće, biskupsko vijeće, pastoralno vijeće (PG 44). Uzajamnost između sveopćega krsnoga svećeništva svih vjernika i punine ministerijalnoga svećeništva biskupa mora se izraziti kroz: a) stil vlasti dijecezanskoga biskupa koji mora biti osoban i zajedničarski; b) konkretne strukture sudjelovanja u organizaciji partikularne crkve (Ghirlanda, 2004, 555). 


\subsection{U odnosu na vrhovnu crkvenu vlast}

Do sad smo vidjeli način na koji se očituje uloga dijecezanskoga biskupa u sinodalnosti njegove partikularne crkve, no sad se nameće pitanje: Koja je uloga pojedinoga dijecezanskoga biskupa u crkvenoj sinodalnosti na razini njegova odnosa s rimskim prvosvećenikom i Zborom biskupa? Za odgovor na to pitanje potrebno je pojasniti pojam uzajamne nutarnje prisutnosti (mutua interioritas) između partikularne i sveopće Crkve iz pisma Communionis notio Kongregacije za nauk vjere (28. svibnja 1992.) koji pokazuje da je partikularna crkva zaseban cjelovit subjekt kad je u njoj prisutna i djelotvorna sveopća Crkva, tj. u mjeri u kojoj partikularna crkva u sebi posjeduje sve veze sveopćega zajedništva (CN 9). Zahvaljujući toj uzajamnosti između partikularne i sveopće Crkve, također se i njihovi pastiri, tj. dijecezanski biskup kao pastir partikularne crkve, te rimski prvosvećenik i Zbor biskupa kao subjekti vrhovne vlasti sveopće Crkve, nalaze u uzajamnom odnosu. Na temelju takvoga odnosa, kao i kolegijalnoga duha uvijek prisutnoga među svim biskupima zajedno s rimskim prvosvećenikom, odakle dolazi obveza dijecezanskih biskupa da imaju skrb za sveopću Crkvu i druge partikularne crkve (LG 23), ne samo da je vrhovna vlast sveopće Crkve prisutna u partikularnim crkvama, nego su također autoritet i vlast dijecezanskih biskupa prisutni u sveopćoj Crkvi, upravo stoga što uzajamna unutarnja prisutnost između partikularne i sveopće Crkve i prisutnost vrhovne vlasti u partikularnoj crkvi uvode službu dijecezanskoga biskupa u dimenziju univerzalnosti, koja se očituje upravo u skrbi dijecezanskoga biskupa za sveopću Crkvu i druge partikularne crkve. Stoga valja naglasiti da, zahvaljujući tim odnosima, dijecezanski biskup uprisutnjuje sveopću Crkvu u svojoj partikularnoj crkvi, te u sveopćoj Crkvi uprisutnjuje svoju partikularnu crkvu.

Za razliku od pisma Communionis notio, koje ne govori o sudjelovanju dijecezanskih biskupa u vlasti rimskoga prvosvećenika, premda spominje termin mutua interioritas između partikularne i sveopće Crkve, CIC kan. 333 \$2 govori o trajnom zajedništvu rimskoga prvosvećenika s biskupima u obavljanju službe vrhovnoga pastira Crkve, a kanon 334 podsjeća kako je potrebno da biskupi pomažu papi u obavljanju njegove vrhovne službe, navodeći neke načine takve suradnje, kao što su Biskupska sinoda i Zbor kardinala.

U svjetlu tih tvrdnji, kao i u svjetlu prije objašnjenih pojmova suodgovornosti i sudjelovanja, postaje očigledno kako se ostvaruje crkvena sinodalnost na razini sveopće Crkve: odnos između dijecezanskoga biskupa i njegova naroda o kojem govori apostolska postsinodalna pobudnica Pastores gregis, kako u slučaju učiteljstva (PG 29), tako u slučaju vlasti (PG 44), mogao bi se analogno primijeniti na odnos između rimskoga prvosvećenika i dijecezanskoga biskupa. Tako primjerice, kao što vjernici pomažu dijecezanskomu biskupu kroz savjetodavna tijela u biskupiji, kao što su biskupijska sinoda, prezbitersko vijeće, biskupsko vijeće, pastoralno vijeće, tako i rimskomu prvosvećeniku, u smislu kanona 333 §2 i 334, u obavljanju njegove primatske službe pomažu biskupi, kroz središnja tijela sveopće Crkve, kao što su Biskupska sinoda, Kardinalski zbor i Rimska kurija. 


\section{Sudjelovanje dijecezanskih biskupa u sinodalnim tijelima}

\subsection{Partikularna crkva}

Nakon što smo iznijeli ulogu i važnost dijecezanskoga biskupa u sinodalnoj strukturi Crkve, sad ćemo pokazati kako se to konkretno ostvaruje u crkvenim tijelima na različitim razinama provođenja sinodalnosti. Kako je predložio papa Franjo u navedenom govoru, na prvoj razini se nalaze partikularne crkve, a među njihovim sinodalnim tijelima na prvom mjestu nalazi se Biskupijska sinoda, kako u Papinu govoru, tako i u Zakoniku (CIC kann. 460-468).

Razlog prednosti toga tijela među ostalima koji se nalaze u službi vlasti jedne partikularne crkve u činjenici je što ono, više od drugih, predstavlja sintezu komponenata cjelokupnoga Božjega naroda, s ciljem koji se proteže sve do sudjelovanja u zakonodavnoj ulozi biskupa (Visioli, 2017, 90). Teološki se temelji na jednakosti svih krštenih u kršćanskom dostojanstvu te u izgradnji Crkve (CIC kan. 208; LG 32).

Jedini član biskupijske sinode koji ima moć odlučivanja jest dijecezanski biskup koji, sazivajući i predsjedajući sinodom, provodi svečani i izvanredni oblik vlasti, no u obliku sudjelovanja, u kojem svaki član sinode čini svoje pravo-obvezu u izgradnji Crkve, premda sudjelujući na različite načine u trostrukoj Kristovoj službi. Tako pastir predsjeda svojom Crkvom i vodi ju zajedno sa svojim stadom, kojemu istovremeno priznaje njegov identitet i njegova prava i obveze (Visioli, 2017, 99).

Drugo tijelo pomoću kojega je moguće provesti sinodalnost na razini partikularne crkve jest prezbitersko vijeće, koje se temelji na sudjelovanju biskupa i prezbitera u hijerarhijskom zajedništvu na jedinom Kristovom svećeništvu i službi (Rivella, 1995, 49). Stoga su prezbiteri suradnici dijecezanskoga biskupa u upravljanju biskupijom radi njezina pastoralnoga dobra (CIC kan. 495 §1). Premda vijeće ima samo savjetodavni glas, biskup ga mora konzultirati u stvarima veće važnosti (CIC kan. 500 §2). Osim toga vijeća, ostala tijela sudjelovanja i suradnje prezbitera u službi dijecezanskoga biskupa u njegovoj biskupiji su: zbor savjetnika, biskupsko vijeće, kanonički kaptol.

Nakon kratkoga spomena biskupijskih tijela svećeničke naravi, vratimo se institucijama u kojima su zastupljene i druge kategorije vjernika, posebno laici. Tako imamo biskupijsko pastoralno vijeće kao oblik sudjelovanja svih vjernika u njihovu zajedništvu u poslanju Crkve, pod autoritetom dijecezanskoga biskupa, koje stvarno odražava Božji narod u jednoj biskupiji (Borras, 2017, 218). Ono predstavlja bitne elemente toga Božjega naroda: temeljnu jednakost u dostojanstvu i u djelovanju, raznolikost, komplementarnost, hijerarhijsko zajedništvo, te stoga biskupijsko pastoralno vijeće, koje je, za razliku od biskupijske sinode, redovito tijelo (CIC kan. 513 §1), mora biti shvaćeno i uspostavljeno kao "znak" biskupije (Gervasio, 2000, 235). Pod tim vidom, nema puno smisla to što kanon 511 pastoralno vijeće vidi kao neobveznim. Osim što je oblik suradnje i dijaloga, kao i razlučivanja na razini biskupije, pastoralno vijeće unaprjeđuje communio ecclesiarum, jer je svako vijeće partikularnih crkvi koje čine jednu crkvenu po- 
krajinu pozvano poslati svoja dva člana da sa savjetodavnim glasom sudjeluju u pokrajinskom saboru (CIC kan. $443 \S 5$ ), potičući tako savjetovanje i suradnju vjernika također na nadbiskupijskoj razini (Gervasio, 2000, 228).

Drugo tijelo koje možemo smatrati sinodalnim, u duhu iznesenih tvrdnji o crkvenom zajedništvu i savjetovanju, jest biskupijsko vijeće za ekonomske poslove, čija je suglasnost ili mišljenje obvezno u slučajevima predviđenim zakonom (CIC kann. 494 §§1-2, 1263, 1277, 1281 §2, 1292 §1, 1305, 1310 §2). Potrebu za mišljenjem ili suglasnošću toga vijeća treba razumjeti kao način sudjelovanja biskupijske zajednice u administrativnom dijelu službe dijecezanskoga biskupa (Perlasca, 2000, 173). Vijeće ne treba smatrati kao tehničku kolateralnu komisiju koja izražava svoje mišljenje ili suglasnost o nekom isključivo ekonomskom pitanju, jer njegova kompetencija mora biti i tehnička i pastoralna, vrjednujući sredstva, ali i cilj za koji se sredstva koriste. Zbog toga vijeće sudjeluje u odlukama pastira tako što promatra pitanja pod svim točkama gledišta te, uostalom, surađuje s njima također $\mathrm{u}$ fazi provedbe.

\subsection{Skupština partikularnih crkvi}

Na toj razini sinodalnost se očituje u krajevnim saborima i biskupskim konferencijama. Krajevni sabori imaju dvostruko teološko utemeljenje: zbornu dimenziju biskupske službe i samu narav Crkve kao zajedništva između partikularnih crkvi. Drugi ekleziološki temelj, zanimljiviji za temu sinodalnosti, ne očituje se samo uz pomoć pastira crkava uključenih u krajevne sabore, nego također po izravnom sudjelovanju u saborima, čak i samo kroz savjetodavni glas, predstavnika različitih kategorija vjernika koji čine Božji narod, a koji obavljaju svoje pravo i dužnost da očituju pastirima svoje mišljenje o onom što se odnosi na dobro Crkve (CIC kan. 212 \$3). Na taj način krajevni sabori očituju sinodalnu strukturu ne samo apostolske službe, nego svih službi pojedinačno i sveukupno (Ghirlanda, 1991, 120).

Svaki biskup, kao član Zbora biskupa, mora pomagati sveopćoj Crkvi i svim ostalim partikularnim crkvama (LG 23). Ta se pomoć ostvaruje na različite načine, među kojima su također biskupske konferencije kao coetus Episcoporum jedne nacije ili određenoga teritorija, u kojem biskupi zajedno obavljaju neke pastoralne funkcije za vjernike toga teritorija (CIC kan. 447), ali ne i svoju cjelokupnu službu, jer kad bi se u biskupskoj konferenciji ostvarilo obavljanje biskupske službe u cijelosti, tad bi konferencija kao institut crkvenoga prava, potpuno ograničila redovitu, vlastitu i neposrednu vlast koju dijecezanski biskupi po božanskom pravu imaju u povjerenim im partikularnim crkvama (CIC kan. 381 §1), a nju može ograničiti jedino drugi institut božanskoga prava, tj. vrhovna vlast Crkve (CIC kann. 331 i 333). Pastoralna služba biskupa šira je od združenoga djelovanja unutar konferencije (Ghirlanda, 2015, 777).

Unatoč tomu, biskupske konferencije kao djelomično ostvarenje kolegijalnoga duha i brige koju svaki biskup iskazuje sveopćoj Crkvi i bližim, partikularnim crkvama, velika su pomoć za pastoralno djelovanje biskupa, jer mnoge poteškoće biskupi ne mogu riješiti niti se s njima suočiti na pojedinačnoj razini, nego jedino 
u svojem udruženom djelovanju (CD 37). Iz toga je moguće zaključiti kako je temeljna narav biskupskih konferencija to što je ona trajni coetus Episcoporum, u kojem biskupi jedne nacije ili određenoga teritorija razmjenjuju iskustva i stavove, međusobno se savjetuju i surađuju radi dobra Crkve, te unaprjeđuju međusobno jedinstvo i jedinstvo Crkve, jačajući crkveno zajedništvo (ApS 6). Na taj se način ostvaruje sinodalnost unutar biskupskih konferencija jer, živeći zajedništvo preko međusobnoga savjetovanja i razmjene stavova, pastiri, članovi biskupskih konferencija, istovremeno imaju priliku da, ako slušaju svoje vjernike u svojim biskupijama, budu glas pastoralnih potreba koje ce prenijeti u razna tijela hijerarhijske strukture Crkve.

\subsection{Sveopća Crkva}

$\mathrm{Na}$ koncu, dolazimo do točke susreta dinamike slušanja i sinodalnoga hoda na svim razinama Crkve, Biskupske sinode, koja trenutačno prolazi kroz ozbiljan proces reforme. Po tom tijelu, sinodalni hod kulminira u slušanju od strane rimskoga biskupa, pozvanoga da se izjasni kao pastir i učitelj svih vjernika (Franjo, 2015, 1141).

Vezu između rimskoga prvosvećenika i Biskupske sinode vidimo u sljedećem tekstu: »Rimskomu prvosvećeniku u obavljanju njegove službe pomažu biskupi koji mu mogu pružati suradnju na različite načine, a jedan je od tih načina Biskupska sinoda « (CIC kan. 334). Ta nam norma već očituje karakteristike crkvene sinodalnosti koje smo razmotrili, a koje su prisutne u Biskupskoj sinodi: sudjelovanje i suradnja skupine vjernika, u tom slučaju biskupa, u obavljanju službe vrhovnoga pastira. Kanon 342 još više produbljuje sinodalnu narav toga tijela kad tvrdi da je Biskupska sinoda skupština biskupa izabranih s različitih krajeva svijeta, koji se sastaju u određeno vrijeme da bi promicali usku povezanost između rimskoga prvosvećenika i biskupa te da bi rimskomu prvosvećeniku savjetima pružili pomoć. Narav Biskupske sinode pokazuje da je ona: a) središnji crkveni institut savjetodavne naravi (AS I i II, 1); b) na neki način predstavlja biskupstvo, jer je znak i sredstvo kolegijalnoga duha i izraz pomoći koju biskupi pružaju za dobro cijele Crkve (Državno Tajništvo Svete Stolice, 2006, 756); c) trajna, jer je stabilna u Crkvi (AS I).

Na koji način dijecezanski biskupi daju svoj doprinos sinodalnosti Crkve unutar Biskupske sinode? Budući da Biskupska sinoda na neki način predstavlja biskupstvo, izražavajući kolegijalnu dimenziju biskupske službe i pomoć biskupa s obzirom na dobro sveopće Crkve, ona sudjeluje u eklezijalnom zajedništvu čitave Crkve po biskupskom zajedništvu među članovima Sinode. Upravo se na zasjedanjima Biskupske sinode na poseban način doživljava crkveno zajedništvo i kolegijalni duh svih članova Biskupskoga zbora okupljenih oko rimskoga prvosvećenika (Eterović, 2006, 438).

Osim toga, biskupi ujedinjeni u Sinodi uprisutnjuju, prije svega, vlastite crkve, potom biskupske konferencije koje su ih izabrale, i, na koncu, na neki način čitav kršćanski puk, jer su njegovi pastiri (PG 58). Ako se načelo slušanja Božjega naroda uistinu poštuje na prve dvije razine ostvarenja sinodalnosti, onda na toj 
posljednjoj razini sinodalni put dostiže svoj vrhunac i najizvrsnije očitovanje, jer pastiri, koji su pozorni na potrebe svojega stada, izražene, među ostalim, i u različitim tijelima sinodalne naravi na razini partikularne crkve i skupština partikularnih crkava, isto će nastojati činiti i unutar Biskupske sinode.

Dvije skupštine Biskupske sinode iz 2014. i 2015., kao i njihova priprema, pokazali su koliko je važno postići sinodalnost na svakoj razini crkvene strukture. Anketni upitnici upućeni biskupskim konferencijama, a preko njih pojedinim biskupijama, župama i vjernicima, kao i spajanje dvaju sinodalnih skupština na istu temu obitelji, važni su trenutci za reformu i obnovu sinodske radne metode. Takva je reforma na konkretan način ostvarena u apostolskoj konstituciji Episcopalis communio objavljenoj 15. rujna 2018., i očituje se u tri elementa: a) pridavanju važnosti pripremi za rad Sinode na razini partikularnih crkvi i skupština partikularnih crkvi, kao i konkretnoj primjeni sinodalnih dokumenata na tim razinama (EC II i IV); b) uvođenju mogućnosti spajanja različitih sinodalnih skupština ili podjele iste skupštine u nekoliko razdoblja tijekom kojih isti članovi $i$ ista sinodalna tijela ostaju na dužnosti (EC I, 3); c) vrednovanju vremena između različitih faza pojedine sinodalne skupštine kao prigode za daljnje produbljivanje ili teološko-pastoralnu studiju (EC I, 3).

S obzirom na ostvarenje sinodalnosti na razini sveopće Crkve, nužno je spomenuti ekumenski koncil kao najsvečaniji događaj u kojem se izražava biskupska zbornost i crkvena sinodalnost, zbog čega je označen kao sacrosancta synodus (LG 1 i 18). Tijekom rada koncila nudi se prilika za razmjenu informacija, mišljenja i iskustava među članovima Zbora biskupa, što konkretno izražava međusobnu suradnju i pomoć među biskupima. Nadalje, ponuđena je i mogućnost da biskupi, nakon što su slušali glas vjernika na razini biskupije i skupština partikularnih crkava, izvještavaju i izražavaju ga u ekumenskom koncilu. Na temelju svega toga biskupi na kraju donose odluku u obnašanju vlasti, koju imaju samo oni. Sinodalnost, razmatrana u svjetlu suodgovornosti, sudjelovanja i savjeta vjernika, mogla bi se ostvariti još šire u pripremi ekumenskoga koncila. Tijekom predpripravne faze zadnjega koncila bili su konzultirani biskupi i drugi prelati, Rimska kurija, crkvena sveučilišta i fakulteti te vrhovni voditelji kleričkih ustanova posvećenoga života. Možemo se pitati može li se, s konzultiranjem laika, redovnika i redovnica, u pripremnoj fazi ekumenskoga koncila, otvoriti još jedna mogućnost ostvarenja još potpunije crkvene sinodalnosti.

Ostala su tijela na razini sveopće Crkve koja su u službi sinodalnoga primata rimskoga prvosvećenika: Kardinalski zbor i Rimska kurija. Osim Biskupske sinode, u kanonu 334 izričito se navode kao suradnici rimskoga prvosvećenika u obavljanju njegove službe također kardinali. Uređenje Kardinalskoga zbora, koji sve više poprima međunarodni karakter, zajedno s posebnim dostojanstvom i povezanošću zbora s primatskom službom, na neki način, čine od toga instituta tijelo koje predstavlja univerzalno biskupstvo pri rimskom prvosvećeniku, ali je na autentičan način prisutan i pri partikularnim crkvama (Arrieta, 2000, 133).

Jednako poimanje Kardinalskoga zbora izrazio je i papa Franjo osnivajući Vijeće kardinala s ciljem da mu pomogne u upravljanju sveopćom Crkvom i prouči 
projekt revidiranja apostolske konstitucije Pastor bonus o Rimskoj kuriji (Franjo, 2013, 875-876).

Kardinalski zbor može doprinijeti ostvarivanju sinodalnosti na razini sveopće Crkve također uz pomoć Konzistorija, kao oblika suradnje u obnašanju službe rimskoga prvosvećenika. To tijelo može postati još učinkovitije u smislu sinodalnosti zbog procesa sve veće i neprekidne internacionalizacije Kardinalskoga zbora, koji može dovesti do većega iskazivanja gledišta, mišljenja i savjeta biskupa sa svih strana svijeta o pitanjima koja su važna za život Crkve (Rivella, 2003, 145).

Sinodalna narav Rimske kurije očituje se u činjenici da, budući da je u službi rimskoga prvosvećenika, s jedne strane usko je povezana s biskupima cijeloga svijeta, a s druge strane sami biskupi i njihove crkve prvi su korisnici službe Rimske kurije (PB 8-9). Osim toga, u skladu s traženjem Drugog vatikanskoga koncila, Rimskoj kuriji valja pribrojiti sve više biskupa, posebno dijecezanskih, koji mogu cjelovitije predstaviti papi mentalitet, želje i potrebe svih partikularnih crkvi, te bi bilo dobro da u radu Kurije sve više budu uključeni vjernici laici koji se odlikuju vrlinom, učenošću i iskustvom, kako bi i oni imali ulogu koja im pripada u Crkvi (CD 10).

\section{Zaključak}

Na kraju možemo zaključiti da figura dijecezanskoga biskupa mora biti odlučujuća za provedbu i ostvarenje sinodalne Crkve prema želji pape Franje. Točno je da veliku važnost ima reforma glavnih tijela sveopće Crkve, kao što su Biskupska sinoda ili Rimska kurija, međutim, ako te reforme nemaju utjecaja na partikularne crkve, sav posao koji se odvija u Rimu neće uroditi plodom tamo gdje je to uistinu potrebno, tj. u svakodnevnom životu i konkretnim situacijama vjernika. Upravo je dijecezanski biskup onaj koji mora poticati izgradnju sinodalnije Crkve, počevši od svoje biskupije, uz pomoć lokalnih tijela u kojima se ostvaruje uzajamni odnos između biskupa i njegova puka, gdje biskup stoji pred drugim vjernicima kao njihov pastir, no istovremeno s njima dijeli zajedničko stanje krštenih u Kristu, zbog čega mora biti "za" i "s" braćom i sestrama, kojima treba priznati i omogućiti pravo da savjetuju svojega pastira i pomognu mu u upravljanju partikularnom crkvom.

Važnost dijecezanskoga biskupa za crkvenu sinodalnost ne ograničuje se samo na razinu partikularne crkve, nego se širi na razinu sveopće Crkve, zahvaljujući uzajamnoj nutarnjoj prisutnosti između partikularne i sveopće Crkve, na temelju koje dijecezanski svećenik uprisutnjuje sveopću Crkvu u svojoj partikularnoj crkvi, ali i partikularnu crkvu u sveopćoj. Ako je uzajamni kružni odnos između biskupa i njegova stada, kako smo već objasnili, ostvaren na razini biskupije, na isti način uzajamni kružni odnos između rimskoga prvosvećenika i Zbora biskupa s jedne, te pojedinačnih biskupa s druge strane, postaje učinkovitiji i daje dobre plodove također na razini sveopće Crkve u njezinim glavnim tijelima, kao primjerice u Biskupskoj sinodi i u Rimskoj kuriji. U svemu tome opet u prvi plan dolazi uloga dijecezanskih biskupa u izgradnji sinodalne Crkve: možemo zaključiti da 
su oni odlučujući za reformu koju papa Franjo želi uvesti u strukturu Crkve, koja uvijek i sve više mora odražavati sinodalnost, zajednički hod Božjega naroda, koji je nezamisliv bez služenja i razboritoga vodstva pastira.

\section{Literatura:}

AG. Ad gentes. Drugi vatikanski koncil, Dekret Ad gentes o misijskoj djelatnosti Crkve. U: Josip Turčinović (ur.), II vatikanski koncil: Dokumenti: Latinski i hrvatski (str. 492-559). Zagreb: Kršćanska sadašnjost, ${ }^{1} 1970$.

Arrieta, Juan Ignacio (2000). Governance Structures within the Catholic Church. Montreal: Wilson \& Lafleur.

ApS. Apostolos suos. (21. svibnja 1998.) Ivan Pavao II., Litterae Apostolicae motu proprio datae: De theologica et iuridica natura Conferentiarum Episcoporum: Apostolos suos. Acta Apostolicae Sedis, (1998) 90, 641-658.

AS. Apostolica sollicitudo. (15. rujna 1965.) Pavao VI., Litterae apostolicae motu proprio datae: Synodus Episcoporum pro universa Ecclesia constituitur: Apostolica sollicitudo. Acta Apostolicae Sedis, (1965) 57, 775-780.

Borras, Alphonse (2017). Sinodalità ecclesiale, processi partecipativi e modalità decisionali. Il punto di vista di un canonista. U: Antonio Spadaro i Carlos María Galli (ur.), La riforma e le riforme nella Chiesa (str. 207-232). Brescia: Queriniana.

CD. Christus Dominus. Drugi vatikanski koncil, Dekret Christus Dominus o pastirskoj službi biskupa. U: Josip Turčinović (ur.), II vatikanski koncil: Dokumenti: Latinski i hrvatski (str. 258-303). Zagreb: Kršćanska sadašnjost, ${ }^{1} 1970$.

CIC. Codex Iuris Canonici. Ivan Pavao II., Zakonik kanonskoga prava. Zagreb: Glas Koncila, 1996.

CL. Christifideles laici. (30. prosinca 1988) Ivan Pavao II., Christifideles laici. Acta Apostolicae Sedis, (1989) 81, 393-521.

CN. Communionis notio. (28. svibnja 1992.) Kongregacija za nauk vjere. Litterae ad Catholicae Ecclesiae episcopos de aliquibus aspectibus Ecclesiae prout est communio: Communionis notio. Acta Apostolicae Sedis, (1993) 85, 838-850.

Coccopalmerio, Francesco (2000). La natura della consultività ecclesiale. U: Mauro Rivella (ur.), Partecipazione e corresponsabilità nella Chiesa: I Con-sigli diocesani e parrocchiali (str. 23-32). Milano: Àncora.

DV. Dei verbum. Drugi vatikanski koncil, Dogmatska konstitucija Dei verbum o božanskoj objavi. U: Josip Turčinović (ur.), II vatikanski koncil: Dokumenti: Latinski i hrvatski (str. 392-416). Zagreb: Kršćanska sadašnjost, ${ }^{1} 1970$.

EC. Episcopalis comunio. (15. rujna 2018) Franjo, Episcopalis comunio. L'Osservatore Romano, 19. rujna 2018, 4-6.

Eterović, Nikola (2006). Biskupska sinoda — razvitak sinodalnosti u Crkvi. Crkva u svijetu, 41, 411-442.

Franjo (2013). Chirographum quo instituitur Consilium Cardinalium ad adiuvandum Romanum Pontificem in Universali Ecclesia gubernanda adque suscipiendum consilium emendationis Constitutionis Apostolicae "Pastor Bonus" de Curia Romana. Acta Apostolicae Sedis, (2013) 105(10), 875-876.

Franjo (2015). Govor Occasione L anniversariae memoriae ab inita Synodo Episcoporum. Acta Apostolicae Sedis, (2015) 107(11), 1138-1144.

Državno Tajništvo Svete Stolice (2006). Ordo Synodi Episcoporum. Acta Apostolicae Sedis, (2006) 98(10), 755-779. 
Gervasio, Giuseppe (2000). Il Consiglio pastorale diocesano, strumento di comunione nella Chiesa particolare. U: M. Rivella (ur.), Partecipazione e corre-sponsabilità nella Chiesa: I Consigli diocesani e parrocchiali (str. 224-249). Milano: Àncora.

Ghirlanda, Gianfranco (1991). Concili particolari e Conferenze dei vescovi: munus regendi e munus docendi. La Civiltà Cattolica, 142(2), 117-132.

Ghirlanda, Gianfranco (2001). Atto giuridico e corresponsabilità ecclesiale (can. 127 CIC). Periodica, 90, 225-272.

Ghirlanda, Gianfranco (2002). Il munus regendi del Vescovo alla luce del can. $381 \S 1$ e del Sinodo dei Vescovi del 2001. Periodica, 91, 677-704.

Ghirlanda, Gianfranco (2004). Linee di governo della diocesi da parte del vescovo secondo l'Es. Ap. Pastores gregis e il nuovo Direttorio per il ministero dei vescovi Apostolorum successores. Periodica, 93, 533-608.

Ghirlanda, Gianfranco (2005). Participación y corresponsabilidad en el gobierno de la Iglesia particular. U: Roberto Serres López de Guereñu (ur.), Iglesia y derecho: actas de las jornadas de estudio en el XX aniversario de la promul-gación del Código de derecho canónico, Facultad de teología "San Dámaso", Madrid, 20-21 de octubre de 2003 (str. 61-94). Madrid: Facultad de teologia "San Dámaso".

Ghirlanda, Gianfranco (2015). Il diritto nella Chiesa, mistero di comunione: Compendio di diritto ecclesiale. Rim: Gregorian \& Biblical Press.

LG. Lumen genitum. Drugi vatikanski koncil, Dogmatska konstitucija Lumen genitum o Crkvi. U: Josip Turčinović (ur.), II vatikanski koncil: Dokumenti: Latinski i hrvatski (str. 91-204). Zagreb: Kršćanska sadašnjost, ${ }^{1} 1970$.

PB. Pastor bonus. Ivan Pavao II., Constitutio apostolica de Romana Curia: Pastor bonus. Acta Apostolicae Sedis, (1988) 80, 841-912.

Perlasca, Alberto (2000). Il Consiglio diocesano per gli affari economici. U: Mauro Rivella (ur.), Partecipazione e corresponsabilità nella Chiesa: I Consigli diocesani e parrocchiali (str. 163-189). Milano: Âncora.

PG. Pastores gregis. Ivan Pavao II., Pastores gregis: Pastiri stada: Postsinodska apostolska pobudnica o biskupu služitelju evanđelja Isusa Krista za nadu svijeta. Zagreb: Kršćanska sadašnjost, 2003.

Rivella, Mauro (1995). Le funzioni del Consiglio presbiterale. Quaderni di diritto ecclesiale, 8, 48-60.

Rivella, Mauro (2003). Il Concilio ecumenico, il Sinodo dei Vescovi e il Concistoro. U: Gruppo italiano docenti di diritto canonico (ur.), Chiese particolari e Chiesa universale. XXIX Incontro di studio, "Villa Cagnola", Gazzada (VA), 1.-5. luglio 2002. (str. 135-147). Milano: Glossa.

Rovira Belloso, Josep María (1997). Vaticano II: Un Concilio para el tercer milenio. Madrid: Biblioteca de autores cristianos.

Sabbarese, Luigi (2012). Consistorio. U: Javier Otaduy, Antonio Viana i Joaquín Sedano (ur.), Diccionario general de derecho canónico: II (str. 661-663). Navarra: Aranzadi.

Villar, José Ramon (2018). La sinodalidad en la reflexión teológica actual. Ius canonicum, $58,69-82$.

Visioli, Matteo (2017). Una forma privilegiata di produzione normativa della Chiesa locale: Il sinodo diocesano. Ephemerides iuris canonici, 57, 73-103.

Vitali, Dario (2001). Sensus fidelium e opinione pubblica nella Chiesa. Gregorianum, 82, 689-717. 
Diocesan Bishops in the Synodal Church

Alan Modrić*

Summary

The article begins with Pope Francis' teachings on synodality, the synodal Church and the meaning of synodality in the juridical system of the Church. It is the intent of this article to explain the diocesan bishop's importance and his role in the fulfillment of synodality. The author includes also an examination of ecclesiastical organs at the diocesan level, of a group of dioceses and in the universal Church. The need is highlighted for greater collaboration between shepherds of the Church and the faithful which could help the Church achieve more profound communion and which would be in accordance with the contemporary Pope's wish for a synodal path for the whole of God's people. On this path, the diocesan bishop is a key figure in the realization of the synodal Church: firstly, at the level of his diocese in which he should acknowledge the right of the faithful to advise their shepherd and assist him in the administration of the particular Church, and secondly, at the level of the universal Church, in constructing a hierarchical communion with the Roman Pontiff and the College of Bishops. The diocesan bishop can help in the administration of the universal Church on behalf of God's people, keeping the needs and dignity of the faithful always in mind.

Key words: synodality, communion, participation, consultation, diocesan bishop.

* Alan Modrić, Ph.D., Pontifical Gregorian University. Address: Piazza della Pilotta 4, 00187 Rome, Italy. E-mail: modric_a@hotmail.com. 